PLANTS PEOPLE

POSSIBILITIES

\title{
Eucommia Ulmoides. The Tu-Chung of the Chinese
}

Author(s): John Parkin

Source: Bulletin of Miscellaneous Information (Royal Botanic Gardens, Kew), Vol. 1921, No. 5 (1921), pp. 177-185

Published by: Springer on behalf of Royal Botanic Gardens, Kew

Stable URL: http://www.jstor.org/stable/4118625

Accessed: 26-06-2016 20:48 UTC

Your use of the JSTOR archive indicates your acceptance of the Terms \& Conditions of Use, available at

http://about.jstor.org/terms

JSTOR is a not-for-profit service that helps scholars, researchers, and students discover, use, and build upon a wide range of content in a trusted digital archive. We use information technology and tools to increase productivity and facilitate new forms of scholarship. For more information about JSTOR, please contact support@jstor.org.

Royal Botanic Gardens, Kew, Springer are collaborating with JSTOR to digitize, preserve and extend access to Bulletin of Miscellaneous Information (Royal Botanic Gardens, Kew) 
ROYAL BOTANIC GARDENS, KEW.

B ULLETIN

OF

\section{MISCELLANEOUS INFORMATION}

No. 5]

$[1921$

\section{XIX.-EUCOMMIA ULMOIDES.}

\section{THE TU-CHUNG OF THE CHINESE.}

\section{John Parkin.}

Our knowledge respecting Eucommia ulmoides, Oliv. has been largely gained from information supplied by Professor Augustine Henry, when resident at Ichang in China 1882-1890, and from the examination of fruiting specimens sent home by him during this period.* It is cultivated in the hilly regions of Central and Western China, and though reported to be wild, has not yet been seen so by Europeans.

The tree is grown by the Chinese for the sake of its bark, which they value highly as a drug, so much so that it commands a fancy price. To us, however, the bark is attractive on account of its containing silky, silvery threads. These can readily be made visible by breaking across a piece of bark and gently pulling apart the two fragments, which are then seen to be held together by numbers of delicate threads. These occur also in the leaves and fruits. They have been regarded as elastic, but this must be more apparent than real, as the material composing them is more akin to gutta-percha than caoutchouc (indiarubber). These substances $\dagger$ as a rule occur in the living plant in the form of minute globules suspended in a watery medium, the two together forming a " milk," which is held in elongated cells or vessels. Hence have arisen the botanical terms, "latex" and "laticiferous tube" for the emulsion and receptacle respectively. Eucommia, however, is exceptional in having its guttalike substance existing in the dry, solid state in the living plant; so no milky juice exudes from any part when punctured. It shares this peculiarity along with the composite Parthenium argentatum (the source of Guayule Rubber) (Kew Bull. 1907, p. $285 ; 1908$, p. $255 ; 1910$, p. 211), and with Chrysothamnus nauseosus (Rabbit bush), a Composite plant of Colorado and

* Oliver, D. Hooker's Icon. Plant., xx., 1890, t. 1950. Kew Bulletin, 1901, p. 89 ; 1904, p. 4.

$\dagger$ An embracing term is much needed for these plant products (caoutchouc, gutta-percha, balata) of which the significant ingredient is a hydrocarbon of the turpene $\left(\mathrm{C}_{10} \mathrm{H}_{16}\right)_{x}$ series. "Elastic gum" is not suitable as only one member of the group is markedly elastic. 
the neighbouring States of North America, which is said to be capable of supplying rubber of fair quality and in large quantities should it ever be needed to supplement that of Hevea brasiliensis.

Taxonomic Position. Systematically this tree occupies a somewhat isolated position. It is the sole member of the genus, Eucommia, which the late Prof. Oliver established for its reception.

From material supplied by Prof. Henry, Oliver* descriked the plant in 1890 and named it Eucommia ulmoides. In a further paper $\dagger$ he refers to the identity of his Eucommia ulmoides with Baillon's Euptelea Davideana, on the authority. of Baillon $\ddagger$ himself, but this identification was not justified, the two plants belonging to quite different generaß. He points out that though the nearest ally of Eucommia would appear to be Euptelea, it differs quite sufficiently to warrant the creation of a new genus for its reception. He further considers that there can be now no reasonable ground for hesitation in separating this genus, Eucommia, along with Cercidiphyllum, Euptelea, Trochodendrom and Tetracentron, from the Magnoliaceae, and in placing them in a distinct family. He agrees to adopt Prantl's name, Trochodendraceae, for this new family, which differs chiefly from the true Magnoliaceae in having naked flowers (no perianth) and in being without oil glands. He lays stress on two features possessed by Eucommia, viz., solitary ovary with bifid stigma and caoutchouc-containing cells, which serve to distinguish it from Euptelea. As regards the first-mentioned feature, it may be asked: Are we to infer that the flower of Eucommia possesses a single carpel only, or that it has really a syncarpous dicarpellary gynoecium? If the latter inference be correct, then Eucommia would seem to be still less related to Euptelea ; in fact its inclusion in the Trochodendraceae would be hardly warranted.

It is not the intention here to discuss fully the systematic position of this interesting tree, but it may be pointed out that Solereder | from his investigation of the female flower considered it syncarpous and dicarpellary, and was inclined consequently to place the plant in the Hamamelidaceae. Van Tieghem 9 likewise did not regard it as belonging to the Trochodendraceae, and to emphasize its isolated position, made a new family, the Eucommiaceae, for its reception. Engler agrees with this view, for in the latest edition of his Syllabus der Pflanzenfamilien (1919) the family, Eucommiaceae, occurs and is put in the cohort, Rosales, next to the Hamamelidaceae.

* Oliver, D. l.c.

+ Oliver, D. Hooker's Icon. Plant., xxiv., 1895, t. 2361.

\$ See letter from Baillon to Oliver in Herb. Kew.

\$ See Hemsley in Hook. Icon. Pl. in syn. sub t. 2787.

|| Solereder, H. Ber. Deutsch. Bot. Gesell., xvii., 1899, p. 387. In this paper the author disputes the identity of Euptelea Davideana Baill. with Eucommia ulmoides, Oliv., and considers it rather to be identical with Euptelea pleiosperma, Hook f. et Thoms. [This opinion was confirmed by Hemsley, l.c.-Ed.]

I Tieghem, van P., Journ. de Bot., xiv., 1900, p. 262; see also Mr. Hutchinson's paper on Winteraceae, p. 185 of this number. 
Further investigation of the flowers of Eucommia and especially of the pistillate ones, would seen desirable in order if possible to gain new light on its real affinities.

Anatomical. Prof. Weiss* in 1892 worked out the development, distribution, and microscopical characters of the cells which elaborate these "elastic" threads in Eucommia. He also investigated to some extent the substance itself extracted from the bark.

Barthelat† and Dybowski et Fron $\ddagger$ have since supplied extra details regarding the structure of these gutta-percha producing elements and their distribution in the plant.

This tree might repay further study from the anatomical side. The wood especially requires minute examination. Facts might possibly be forthcoming which would throw light on its relationship.

The Gdtta-like Material. Weiss considered the substance composing the "elastic" threads of the bark to be of the nature of caoutchouc from its behaviour towards solvents. Consequently the specialised elements in the plant holding this material came to be termed caoutchouc-containing cells, and the tree itself to be spoken of as a rubber-yielding one for temperate climates.

Dybowski et Fron $\ddagger$ from their economic enquiry came to the conclusion that the substance is much nearer akin to guttapercha than caoutchouc. A French authority to whom they submitted a sample declared it to be gutta of good quality.

Sievers§ in a recent paper, apparently unaware of the French work, treats the substance as rubber and investigates its solubilities in various media.

In order to arrive at a rough idea of the amount of this material contained in the bark, Weiss ground up some of the latter and then extracted it with chloroform. He obtained a yield of 3 per cent. Oliver working independently with another sample of bark secured the same yield. Sievers by ether extraction obtained only a yield of 2 per cent. Dybowski et Fron estimated quantitatively the amount in the dried leaves and found that the percentage of gutta reached $2 \cdot 25$. The fruits were richer in the substance. Apparently the percentage in the bark was not ascertained by them.

In 1910 two bales of Eucommia bark secured in China came into the writer's possession. One bale contained $56 \mathrm{lbs}$. of bark and the other, though not weighed, presumably held half this quantity, judging from its size. During the rubber boom of that year considerable interest was taken in Eucommia. This, however, soon subsided and nothing of importance was published at that time regarding this tree, which was commonly p. 243.

* Weiss, F. F., Trans. Linn. Soc., London, 2nd ser. Bot. III, 1892,

$\dagger$ Barthelat, Journ. de Bot. xiv., 1900, p. 55.

$\mp$ Dybowski et Fron, Comptes Rendus, cxxix., 1899, p. 558.

$\S$ Sievers, A. F., Journ. Amer. Chem. Soc., xxxix., 1917, p. 725. 
spoken of as a hardy rubber-yielding one, in spite of the French work, already referred to, published ten years previously. The writer at this period took up the investigation of the bark. A preliminary examination convinced him that the substance had not the characteristics of rubber. On the other hand though resembling gutta-percha, it was found to be tougher and less plastic on heating.

Extraction by means of solvents is not, as a rule, to be recommended for rubber, gutta and such like bodies, as their desirable physical properties are apt to suffer in the process. Mechanical separation, when possible, is to be preferred. A firm of engineers interested in the rubber industry undertook in 1911 to experiment with the bark. The smaller bale was delivered over to it and attempts were made to separate the gutta-percha from the Eucommia bark; but the results were not satisfactory. The substance could not be obtained free from particles of bark. With the rapid fall in the price of raw rubber from the boom figures of 1910, interest fell off in new sources of rubber and allied substances, and business firms were no longer eager to experiment with unknown barks.

After the war Dr. P. Schidrowitz, to whom I am indebted for the information below, kindly undertook the investigation of the larger bale of bark and managed with some difficulty to separate in a clean state the gutta-like substance, which is tough and almost horny in consistency, and has the dark colour of most raw rubbers, but without their elasticity It is quite free from stickiness. By mechanical extraction the bark yields about two per cent.; whereas that of ordinary gutta trees gives twice or thrice this quantity.

The composition of this material is approximately as follows :-

\begin{tabular}{|c|c|c|c|c|c|c|}
\hline Moisture & e & - & - & - & $5 \cdot 0$ & per cent. \\
\hline Ash & - & - & - & - & $2 \cdot 5$ & u \\
\hline Resin & - & - & - & - & $70 \cdot 0$ & \\
\hline "Gutta- & -percha" & - & - & - & $-\quad 22 \cdot 5$ & , \\
\hline
\end{tabular}

i.e., hydrocarbon $\left(\mathrm{C}_{10} \mathrm{H}_{16}\right)_{x}$

It thus has a higher percentage of resin and a lower percentage of $\left(\mathrm{C}_{10} \mathrm{H}_{16}\right) \times$ hydrocarbon than the raw gutta-percha of commerce, obtained from sapotaceous trees.

As regards its physical properties and economic possibilities Dr Schidrowitz wrote to me in March, 1920, as follows :"The material is not as plastic as high grade gutta-percha. It is very tough, but the gutta-after extracting the resins-is decidedly 'short' and does not compare favourably with ' hardened ' (i.e., extracted) gutta-percha. The electrical (insulation) properties are probably similar to certain grades of gutta, but so far as 'ageing' goes, the indications are that it does not compare favourably with good gutta. Of course, at a really low price (say $1 /-$ to $1 / 6$ per lb.) a use might be found for it, but I gather that anything of that kind is out of the question. 
To get reliable tests as to strength, \&c., I should need a good deal more of the material than I have."

Since then it has been found that mechanically extracted Eucommia gutta soon becomes brittle with age, which would render it well nigh useless for electrical purposes.

Medicinal Properties. Eucommia bark is held in high esteem as a medicine by the Chinese and is said to have invigorating and arthritic properties; but it is doubtful whether the bark really contains any principle of therapeutic value. A cursory examination of the dry bark from this point of view has resulted in the extraction of only a minute quantity $(0.038$ per cent.) of presumed alkaloid.

The Chinese believe in the doctrine of signatures, which asserts that a plant shows some resemblance to the organ of the body, for the disease of which it is useful; and the peculiar threads in this bark may have suggested its use as a drug to the Chinese.

The writer has still a little bark and some dried leaves at his disposal should anyone care to investigate Eucommia further from the medicinal aspect.

Growth and Behaviour of the Tree in the British Isles. France was the first European country to receive the living plant from China-apparently about 1890 . Kew obtained in 1897 one Eucommia plant from M. Maurice de Vilmorin. This flowered for the first time in 1909 and proved to be a male tree. The other trees there have been propagated vegetatively from the original one. Some years ago information was supplied by Kew* respecting the hardihood, cultivation, and propagation by cuttings of Eucommia. Last winter Mr. W. J. Bean kindly furnished me with up-to-date details regarding the trees at Kew. He wrote as follows :- "At present we have four trees viz., the original one which never having been trained, has remained bushy and comparatively low; and three trees raised from cuttings taken from the original tree. The largest of these is now about 23 feet high, its trunk 22 inches in girth and clear of branches up to 7 or 8 feet. The other two have trunks 21 and 16 inches in girth respectively." He proceeds to say that pruning and training were found to be necessary to produce the tree-form in Eucommia, but thinks that if they were planted close enough they would form trees naturally.

The Royal Botanic Gardens, Edinburgh, $\nmid$ possess two trees. They were raised from Wilson's seed, No. 383, and were planted in their present position in 1911 in prepared ground on a lawn. They now measure $\ddagger$ respectively in height 8 and 5 feet and in girth $5 \frac{1}{2}$ and 4 inches. They are bushy and have notyet flowered.

* Gardeners' Chronicle, xxxiii, 1903, p. 104. Kew Bulletin, 1904, p. 4.

+ From information supplied by the Regius Keeper, dated 9.xii.20.

† The messurements recorded in this paper were taken in each case last winter (1920-21). 
There are likewise two plants in the Royal Botanic Gardens, Glasnevir,* Dublin, which were raised from Wilson's seed and have been growing there about ten years. One is 15 feet high on a single stem and the other 8 feet and bushy. Both are thriving.

There are also two trees growing in the University Botanic Gardens, $\uparrow$ Cambridge. One was obtained from Veitch and Son in 1905 and is 16 feet in height with a girth of 10 inches. The history of the other is uncertain. It is nearly 15 feet high with a girth of 12 inches. They are both growing in ground kept free from grass and weeds and are tree-like in habit.

Reports were also received last winter from several private British gardens and I wish here to express my thanks to the writers of the same.

At Sprowston Hall, near Norwich, Sir Eustace Gurney planted some Eucommias about ten years ago. They were obtained from M. de Vilmorin and were apparently rooted cuttings. All but two have been discarded. These are now only 12 feet high and 9 inches in girth, though well-sheltered and growing in good soil, kept free from grass.

Mr. Reginald Cory has two trees growing at Duffryn, near Cardiff. One obtained from Veitch and Sons, planted 1911 and once transplanted since, is now $15 \frac{1}{2}$ feet high and nearly 8 inches in girth. It is growing in cultivated ground and is tree-like in habit. The second tree was obtained as a sucker from the former 5-6 years ago and has grown well, being over 13 feet in height.

Mr. Gerald Loder possesses three trees, growing at Wakehurst Place, Ardingley, Sussex, also obtained from Veitch \& Sons. One planted in 1910 in poor dry soil is 11 feet high (once had its top blown off) and 9 inches in girth. The other two planted in 1914, one in deep loam and the other in clay, are respectively $9 \frac{1}{2}$ and 9 feet high and 3 and $4 \frac{1}{2}$ inches in girth. The trees were planted carefully with the idea of keeping the ground clear of grass, but owing to the war this has been largely neglected.

Several trees, raised from Wilson's seed and planted probably between 1911-13, are growing in heavy clay at Aldenham House, Elstree, Herts. Measurements of three of these have been sent by the Hon. Vicary Gibbs, who states that these would approximate to those for the other trees. Their heights and girth respectively are 12 feet and 8 inches : $10 \frac{1}{2}$ and $5: 9 \frac{1}{2}$ and 5 .

All the reports received agree in one particular, namely, that Eucommia is perfectly hardy. At Duffryn the trees came through unharmed the winter of 1916-17, when 26 degrees Fahrenheit of frost were registered. At Aldenham they have withstood a temperature even below zero Fahrenheit.

Respecting all the above trees flowering has only been observed in the case of the Kew trees.

* From information supplied by the Keeper through Prof. Henry, dated 3.xii.20.

$\dagger$ From information supplied by the Superintendent, dated $16 \&$ 24.xii.20. 
In the spring of 1910 the writer obtained from France a specimen of Eucommia. It was planted in a sunny portion in cultivated ground in a Cumberland garden, situated 200 feet above sea level and 8 miles inland. It has grown very well and has the following dimensions : height 17 feet, girth 13 inches. The severe frost we experienced in the north-west of England in November, 1919, killed a fair amount of the previous summer's growth of this tree. Male flowers were observed on it for the first time in the spring of 1919. It has bloomed in a similar fashion both last spring and this, without any signs of female flowers.

In April, 1911, I obtained two plants from Messrs. Barbier et Cie., Orleans One was planted in the open on grass in a frosty situation. It did not survive the following winter. The other one was put in cultivated garden soil and has once been transplanted. It is now $9 \frac{1}{2}$ feet high and 4 inches in girth.

In the autumn of the same year I obtained two dozen oneyear seedlings which had been raised from Wilson's seed. They were wintered in a cold greenhouse and planted in the garden the following spring, where they grew well under cultivation. The attempt, however, to establish them in the open under forestry conditions has not met with success. Seventeen of them were pitted, mainly in the spring of 1916, along with other deciduous trees on a rough grassy bank. Ten of these have died and the remaining seven, though living, are not flourishing and may ultimately succumb. The new growth does not ripen sufficiently to withstand the frosts of winter and more especially the bleak winds of early spring. It would seem that in order to establish a plantation of Eucommia, in this part of England at any rate, cultivated ground with shelter would be necessary.

Eucommia, though a quick grower, has not a very satisfactory tree-habit of growth. It is inclined to put its energy into subordinate sucker-like shoots, rather than into a single main leader. These shoots may attain as much as three feet in length during one season and are probably induced through the dying back of some of the last summer's growth. The tendency to a spreading, bushy, habit may be overcome to some extent by training and pruning. It remains to be seen whether Eucommia when closely planted would assume the tree-habit naturally and be drawn up with a straight stem.

Apparently plants raised from cuttings produce as good specimens as from seeds; though as to the ultimate height and girth reached by trees propagated in these two ways, no particulars are to hand. The plant cannot be raised from cuttings in the same easy manner as succeeds with willows, poplars, roses, etc. They require to be taken from the current year's growth in the middle of summer and subjected to gentle bottom heat. Probably layering might be found a more successful way of increasing this tree. Apparently it is one that would sucker freely and by this means shoots would be provided for layering. 
The dearth of flowers calls for some comment. So far only the Kew authorities and myself have reported the production of flowers (male ones in both cases) by Eucommia in this country. As they are inconspicuous, they could be easily overlooked by anyone not familiar with them and not especially interested in the plant. They are produced just before the leaves in late April or early May, and the greenish-yellow appearance they give the tree might be mistaken for the bursting forth of the foliage leaves. This refers to the male (staminate) blooms only, but judging from analogy the female (pistillate) ones are likely to be even less noticeable. It is therefore quite possible that Eucommia may have flowered elsewhere in the British Isles, but the occurrence has escaped notice.

The tree is regarded as dioecious, and if this be correct then the offspring arising vegetatively from a single seedling will all be of one sex. This might account for the staminate nature of the British trees which have been observed to flower; but the behaviour of the Eucommias in the Arnold Arboretum suggests something more than chance in the non-production of female flowers. Professor Sargent informs me that the trees there have flowered for a number of years and are all staminate, and that he does not know of a pistillate plant in cultivation. Is the tree really dioecious? It may be monoecious and if so either climate or more likely age may influence the production of female flowers, and if so a fresh batch of seedlings may still disappoint in producing only male flowers. The plant evidently requires further study in China as regards its manner of flowering.

Economic Possibilities. The cultivation of Eucommia as a source of gutta-percha would appear to be a very doubtful economic undertaking, even if its gutta were found to be of commercial value. Anyone interested in trees and not minding expenditure which might never be remunerative, would by planting an acre, or even a less area, of this tree afford an instructive lesson as regards its sylvicultural possibilities. The experiment should preferably be tried in a mild part of the kingdom, such as the S.W. of England or of Ireland. There would then be little danger of the crippling effect of frost on the previous summer's growth, and at the same time conditions would be favourable for the assumption of the tree-rather than the bush-habit of growth

Given a use for the gutta-like substance and quick growth of the plant, there would still be drawbacks to be faced in its cultivation as an economic tree, viz.:-

1. The yield from the bark is low.

2. The gutta is not easily separated mechanically from the bark. This, however, might be overcome by engineering ingenuity.

3. As the gutta exists in the dry state in the living plant, it could not be extracted by tapping as in laticiferous trees. Hence a Eucommia tree could only give a yield of gutta once 
by felling it and stripping it of its bark, $(a)$ unless the substance could be extracted economically from its leaves or annual prunings, (b) or unless some means of paring off the bark without destroying the cambium could be devised, (c) or unless the tree were amenable to the coppice system. The last possibility is perhaps the most likely. In this case the peeled poles might form a subsidiary source of revenue.

4. High cost of land and wages.

In conclusion the writer would like to take this opportunity of expressing his thanks to Prof. Augustine Henry for much help in the compilation of these notes.

\section{XX.-THE FAMILY WINTERACEAE.}

\section{J. Hutchinson.}

The family Winteraceae, as here understood, has usually been regarded as a tribe of Magnoliaceae, and it stands as such in the classifications of Bentham and Hooker (Genera Plantarum, i. 17), and Engler and Prantl (Die Natürl. Pflanzenf. iii. ii. 18). In the following brief notes the present writer gives reasons for separating the group from the true* Magnoliaceae, represented by the genera Michelia, Linn., Mangiietia, Bl., Talauma, Juss., Aromadendron, Blume, Magnolia, Linn., and Liriodendron, Linn. This segregation has become more imperative since the Trochodendraceae and Himantandraceae have been taken out of Magnoliaceae, and some degree of uniformity of treatment is now possible.

Robert Brown $\dagger$ was the first to point out that the genera Illicium and Drimys should be distinguished as a separate family from Magnoliaceae, and for them he proposed the name Wintereae. Lindley, for a time, and J. Miers took a similar view, as did also Endlicher, who expressed the opinion (Enchir. Bot. 428), that the group ought to rank as an independent family, although later (Genera Plantarum 836), he included them as a sub-family of Magnoliaceae. Even J. D. Hooker and T. Thomson (Fl. Ind. 72), say that " the Wintereae form a very questionable tribe of Magnoliaceae, and may with reason be separated from them." Hooker, however, as already indicated, included them in the Magnoliaceae.

* Other genera referred to the Magnoliaceae are Trochodendron, Sieb. et Zucc., and Euptelea, Oliv., which constitute the distinct family Trochodendraceae, and Cercidiphyllum, Sieb. et Zucc. the Cercidiphyllaceae Eucommia, Oliv., and Tetracentron, Oliv., are better placed with the Hamamelidaceae, whilst Himantandra, F. Muell. (= Galublimima, Bailey), a remarkable genus incorrectly reduced by Mueller himself to Eupomatia (Annonaceae), has recently been made the type of a new family, Himantandraceae (see Diels "Über die Gattung Himantandra, ihre Verbreitung und ihre systematische Stellung," in Engl. Bot. Jahrb. lv. 126-131, fig. i (1.917)).

$\dagger$ R. Br. apud DC. Syst. Veg. i. 548 (1818); De Candolle, however, treated them as a tribe, Illiceae of Magnoliaceae. 